\title{
Chip pattern, burr and surface roughness in laser assisted micro milling of Ti6Al4V using micro ball end mill
}

\author{
Z. Mohid ${ }^{*}$ and E.A. Rahim ${ }^{1}$ \\ ${ }^{1}$ Precision Machining Research Centre (PREMACH), Faculty of Mechanical \& \\ Manufacturing Engineering, Universiti Tun Hussein Onn Malaysia \\ Email: zazuli@uthm.edu.my \\ Phone: +6075438441; Fax: +6074536080
}

\begin{abstract}
The effectiveness of laser heating could easily fluctuates when the uncut chip thickness are extremely inconsistent. In the case of using micro ball end mill tool, rubbing mechanism is inevitable due to its radial shape geometry. Furthermore, the scenario could be worst when the workpiece is a ductile material which has low thermal conductivity such as Ti6Al4V. Thus, characterization study was carried out to evaluate the feasibility of micro ball end mill in laser assisted micro milling operation. The chip, burr and surface roughness from conventional and laser assisted micro milling were compared and discussed. It is understood that the chip pattern indirectly gives significant influence to the effectiveness of laser assisted micro milling technique. With tool edge radius of $2 \times 10^{-3} \mathrm{~mm}$, feed value of $3.0 \times 10^{-3} \mathrm{~mm}$ produced more consistent surface roughness compared to feed value of 2.1 and $4.2 \times 10^{-3} \mathrm{~mm}$. The machining parameters which produced continuous and conical chips ended up with sever burr formation and surface roughness inconsistency.
\end{abstract}

Keywords: Laser assisted micro milling; chip pattern; burr; surface roughness; Ti6Al4V

\section{INTRODUCTION}

Laser assisted machining technique combines heating process and milling process to allow the removal process to be done under preheated state $[1,2]$. This technique is reported effective in machining of difficult-to-machine materials with high hardness $[3,4]$. Heating the workpiece helps to reduce the hardness and maximum temperature increment caused by shearing and friction mechanisms. The workpiece properties are temporarily modified, allowing the milling process done under lower mechanical and thermal load. The machining process managed to be done under lower cutting force and cutting temperature [5,6], thus improve machining surface quality and tool life.

However, this technique has comparatively larger number or process influencing factors which leads to performance inconsistency [4]. The machining performance could fluctuates by two major categories of parameters namely laser heating and milling process. Laser heating parameters such as laser power, laser beam diameter and power intensity distribution modes contribute largely to temperature distribution characteristics [7]. The achievable heating temperature at cutting area will finally determine the level of softening effect at cutting area. On the other hand, Milling parameters such as feed per tooth $(f)$, depth of cut $\left(t_{c}\right)$ and 
cutting speed $\left(v_{c}\right)$ determine the removal process mechanism by altering the value of uncut chip thickness and the temperature at the cutting area [8,9].

Laser assisted milling/ micro milling on various materials including titanium alloy has been reported with significant improvement. Most of the study used flat end mill and insert cutting tools [10-14] and generally focused on the cutting force and tool wear characteristics. Recent study in laser assisted milling using ball mill tool were also reported but using macro size tools and not focused on titanium alloy as the workpiece [14-18]. Furthermore, less has been reported on the effect of machining parameters to the chips formation mechanism and machining quality in laser assisted micro ball milling process.

The study on laser assisted micro machining performance using micro ball end mill tool was firstly reported by Melkote et al. [1]. In the study, Ytterbium doped continuous wave near IR $(1.06 \mathrm{~mm})$ fibre laser with diameter and laser power of $\sim 0.16$ $\mathrm{mm}$ and $7 \mathrm{~W}$ respectively was used as the laser source. Four flutes micro ball mill with diameter of $0.25 \mathrm{~mm}$ was used to perform machining on hardened A2 steel. Lower surface roughness, lower tool wear rate and better dimensional accuracy were obtained with the assist of laser heating.

In the case of micro ball end mill, geometrical factors expose the removal process to intense rubbing and ploughing effect [19, 20]. Furthermore, the chips evacuation efficiency in laser assisted micro milling could be worst when the material is heated, softened and more ductile [8]. Due to the tool geometrical factor, the chips are formed in complicated shapes by multiple of strain vectors and tends to remain in the cutting area. Forces act in multiple directions and the high gradient of cutting velocity produces variant of strain rate in the cutting zone leading to poor surface roughness [21]. In addition, tool size effect and minus rake angle [8] predominantly give influence to chip formation characteristics and cutting performance when the tool is in micro scale size.

Long chips should be avoided to prevent entanglements around the cutting area which could lead to cutting tool and cutting surface damages [22]. Continuous and excessive ploughing mechanism promotes temperature rise at the cutting zone which consequently increases the tool wear rate [23]. Burr formation is another problem that need to be considered when the material is heated and softened due to tearing failure during the removal process [24]. At the tool bottom, comparatively large cutting edge radius induce peculiar effects, erratic force variation and causing extensive burr formation [25].

To produce machining surface with a consistent and small roughness, understanding the actual mechanism occur during the machining process is crucially important. Small uncut chip thickness tends to produce inconsistent surface roughness due to ploughing and elastic recovery which finally generate uneven plastic flow [26]. Considering that titanium alloy possesses low thermal conductivity, machining this alloy using laser assisted micro ball end mill could adversely worsen the machining performance. Localised heat increment could promotes tool wear rate when the heat is continuously conducted from the workpiece to the cutting tool [27-29].

This study was carried out to investigate the feasibility of laser assisted micro milling when using micro ball end mill on ductile (Ti6Al4V) material. A new approach was implemented to minimise the effect of ploughing and rubbing mechanism and to eliminate large temperature gradient at the machining area. The tool was set in tilted orientation and relatively large laser irradiation spot diameter was applied. The 
feasibility of micro ball end mill in laser assisted micro milling operation through chip pattern, burr and machining surface condition. The effect of laser heating to the chip formation and machining surface conditions were evaluated by comparing between conventional and laser assisted micro milling.

\section{EXPERIMENTAL SETUP}

Laser beam head is placed at the inclination angle $\left(\theta_{i}\right)$ of $55^{\circ}$ from $X-Y$ plane in $Y-Z$ plane direction as shown in Figure 1. A laser focusing head with focal length and focusing diameter of $60 \mathrm{~mm}$ and $0.700 \mathrm{~mm}$ respectively was applied. The tool was placed at the inclination of $80^{\circ}$ from $X-Y$ plane in $X-Z$ plane direction to minimise the forces generated during the cutting process [30]. All experiments were conducted under stagnant air and controlled room temperature of $28{ }^{\circ} \mathrm{C}$.

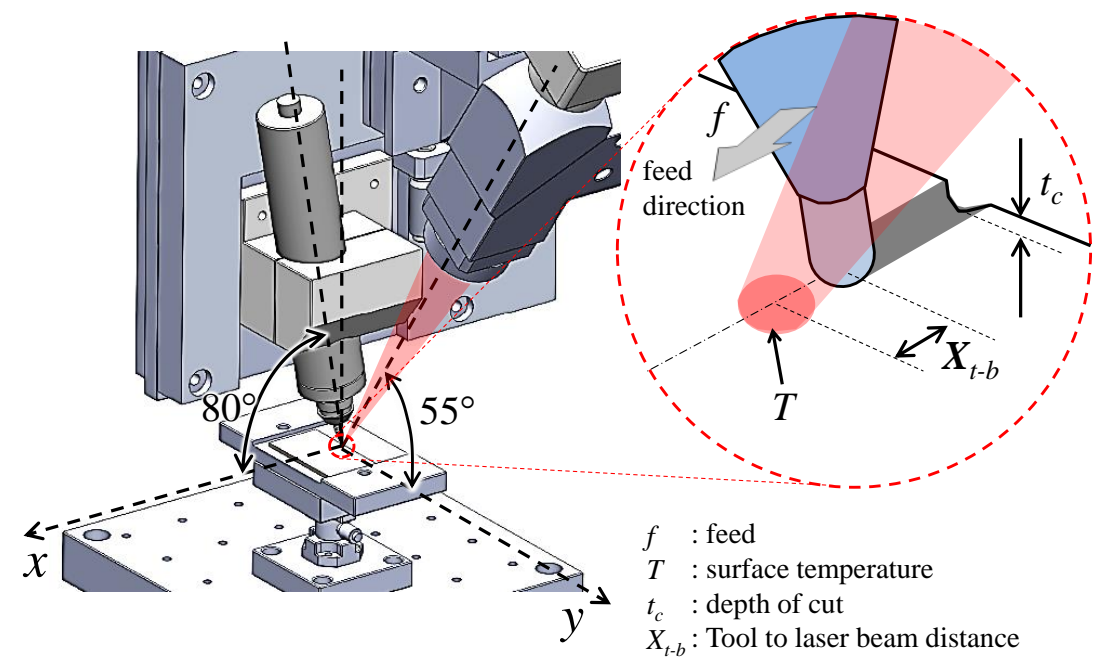

Figure 1. Micro milling tool and laser beam orientation

Table 1. Milling parameters

\begin{tabular}{ccc}
\hline$f \times 10^{-3}(\mathrm{~mm} /$ flute $)$ & $t_{c}(\mathrm{~mm})$ & {$\left[v_{c}(\mathrm{~m} / \mathrm{min}) / f_{r}(\mathrm{~mm} / \mathrm{min})\right]$} \\
\hline $2.1,3.0 \& 4.2$ & 0.020 & {$[7.6 / 52.5],[10.6 / 74] \&[15.1 / 105]$} \\
& 0.045 & {$[9.7 / 75],[13.6 / 105] \&[19.4 / 150]$} \\
& 0.070 & {$[10.9 / 105],[15.3 / 147] \&[21.8 / 210]$} \\
\hline
\end{tabular}

In this study, two flute TiAlN coated cemented carbide micro ball mill with diameter of $0.3 \mathrm{~mm}$ was used to produce grooves. Linear grove machining with length of $25 \mathrm{~mm} /$ path was performed on Ti6Al4V plate with thickness, width and length of 1.8, 25 and $40 \mathrm{~mm}$ respectively. The machining process were performed using variable feed $(f)$, cutting speed $\left(v_{c}\right)$ and depth of cut $\left(t_{c}\right)$ in both machining techniques; conventional (Conv. $\mu$ Mill) and laser assisted micro milling (LA $\mu$ Mill) (Table 1). In Conv. $\mu$ Mill, the workpiece temperature was controlled at $28^{\circ} \mathrm{C}$, while the workpiece temperature in LA $\mu$ Mill varied by the laser heating parameters applied.

The $80^{\circ}$ of tool inclination from $X-Y$ plane has made the tool effective diameter $\left(\emptyset_{t_{-} \text {effect. }}\right)$ become $0.193,0.247$ and $0.248 \mathrm{~mm}$ at $t_{c}$ of $0.020,0.045$ and $0.070 \mathrm{~mm}$ respectively (Figure 2). To perform machining with three levels of $f$ of 2.1, 3.0 and 4.2 
$\times 10^{-3} \mathrm{~mm} /$ flute, three spindle rotation $(N)$ of $12.5,17.5$ and $25.0 \times 10^{3} \mathrm{rpm}$ were applied. The value of $v_{c}$ were taken from the maximum values obtained from calculation using the $\varnothing_{t_{-} \text {effect }}$ and $N$ applied. This configuration has made the $v_{c}$ varied by $t_{c}$ values. At $t_{c}$ of $0.020 \mathrm{~mm}$, different $N$ values of $12.5,17.5$ and $25.0 \times 10^{3} \mathrm{rpm}$ has made the machining process performed at three different $v_{c}$ of $7.6,10.6$ and $15.1 \mathrm{~m} / \mathrm{min}$ respectively. At $N$ of $12.5,17.5$ and $25.0 \times 10^{3} \mathrm{rpm}$, increasing the $t_{c}$ to $0.045 \mathrm{~mm}$ has increased the $v_{c}$ to three different value of $9.7,13.6$ and $19.4 \mathrm{~m} / \mathrm{min}$ respectively. At $t_{c}$ of $0.070 \mathrm{~mm}$, three different $v_{c}$ of $10.9,15.3$ and $21.8 \mathrm{~m} / \mathrm{min}$ were recorded.

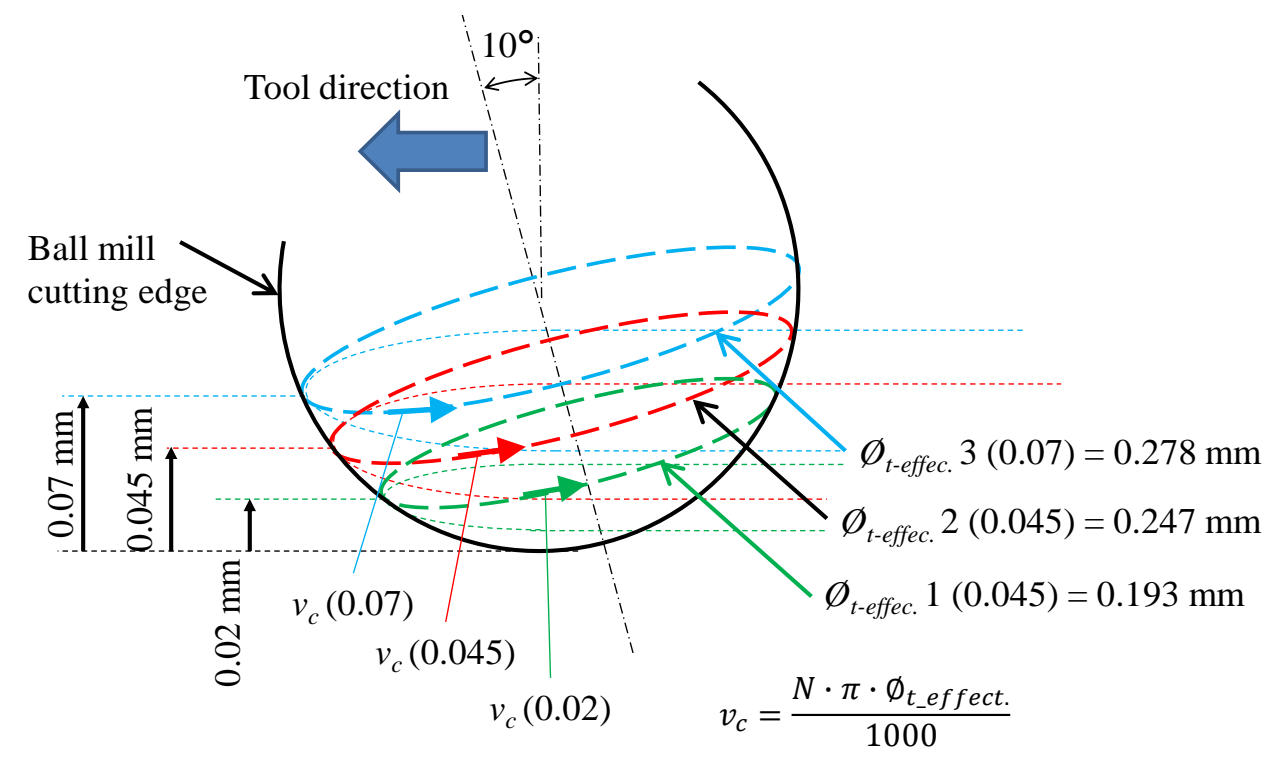

Figure 2. Relation between cutting speed $\left(v_{c}\right)$ and depth of cut $\left(t_{c}\right)$

Table 2.Laser heating parameters in LA $\mu$ Mill

\begin{tabular}{lc}
\hline Items & Values \\
\hline Laser average power, $P_{\text {avg }}(\mathrm{W})$ & 3.4 \\
Pulse on time, $t_{p}(\mathrm{~ms})$ & 1.0 \\
Pulse repetition rate, $f_{p}(\mathrm{~Hz})$ & 100 \\
Tool to laser beam distance, $X_{t-b}(\mathrm{~mm})$ & 0.6 \\
Tool orientation angle, $\theta_{t}\left({ }^{\circ}\right)$ & 80 \\
Feed rate, $f_{r}(\mathrm{~mm} / \mathrm{min})$ & Refer Table 1 \\
\hline
\end{tabular}

In LA $\mu$ Mill, the laser setting parameters are shown in Table 2. To avoid the workpiece from the creation of heat affected zone (HAZ) and melted zone (MZ) in LA $\mu$ Mill, a constant $P_{a v g}, t_{p}$ and $f_{p}$ of $3.4 \mathrm{~W}, 1 \mathrm{~ms}$ and $100 \mathrm{~Hz}$ respectively were applied. This laser heating parameters was confirmed applicable to heat the workpiece with maximum temperature not exceeding $950{ }^{\circ} \mathrm{C}$ which is the Ti6Al4V phase transformation temperature.

The distance between the laser beam centre and the cutting tool centre $\left(X_{t-b}\right)$ was set at $0.6 \mathrm{~mm}$. A gap of $0.1 \mathrm{~mm}$ between the laser irradiated area and tool outer diameter was applied to avoid direct laser irradiation onto the cutting tool, workpiece drastic temperature fluctuation and workpiece material sputtering effect. 
The temperature of the area which has direct contact with the micro ball milling cutting edges were determined by finite element method (FEM) simulation.

The simulation model was validated by results comparison with the experiment using thermocouple embedded $0.05 \mathrm{~mm}$ under the workpiece surface at three different laser irradiation feed rate of 52.5, 105 and $210 \mathrm{~mm} / \mathrm{min}$. Using the validated model, the temperature history and distribution of of the heated surface at the centre line of the irradiation path were recorded and used to estimate the maximum temperature at the cutting area. The results has shown that at three levels of $t_{c}, f$ and $v_{c}$, the workpiece top surface temperature at the cutting area in LA $\mu$ Mill were estimated between 128 and $178{ }^{\circ} \mathrm{C}$. The estimated workpiece temperature at different $f_{r}$ and $t_{c}$ are plotted in Figure 3.

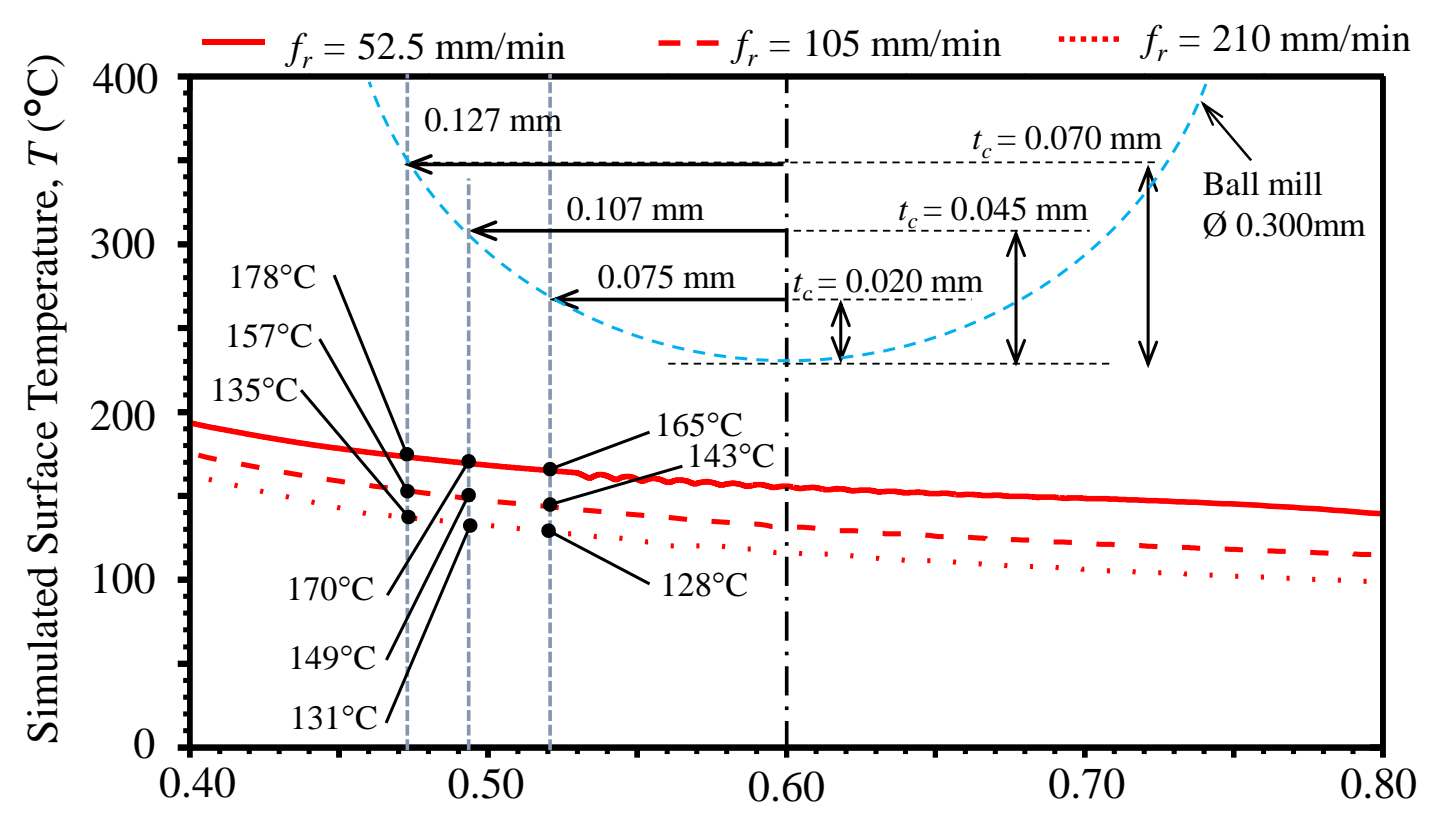

Distance from laser irradiation center, $X(\mathrm{~mm})$

Figure 3. Estimated workpiece temperature at the cutting area in LA $\mu$ Mill under different $f_{r}$ and $t_{c}$.

The chips produced and scattering on the workpiece were collected using double side tape and carbon tape after the first machining path $\left(X_{c}\right.$ of $\left.25 \mathrm{~mm}\right)$. High magnification micro scope was used to observe the chips pattern differences between different machining parameters. Scanning electron microscope was used for better image quality and larger magnification ratio. The width and length of single chips were measured randomly from the chips with good orientation and measurable. The chips thickness was not able to be measured due to the difficulty to get the measurable orientation.

The burr and cutting surface topography were observed under SEM while the cutting surface roughness was measured using table top roughness measuring machine. Sampling length $\left(\lambda_{c}\right)$, sampling size $\left(I_{n}\right)$ and stylus tip radius $\left(r_{t i p}\right)$ of 0.08 , 0.4 and $0.002 \mathrm{~mm}$ respectively were applied for the roughness measurement, according to the EN ISO 4288 standard. The surface roughness of three locations at the machining groove (entrance, middle and exit side) were measured and averaged. 


\section{RESULTS AND DISCUSSION}

\section{Chip Formation Characteristics}

Table 3 shows the distribution of each different chips pattern. Based on the observation on chips produced from different machining parameters and methods, the chips can be divided into three main categories: loose arc, conical and continuous.

From the table, it can be seen that at $t_{c}$ of $0.020 \mathrm{~mm}$, loose arc chips were produced when the feed $(f)$ was $0.003 \mathrm{~mm} /$ flute. When the $t_{c}$ was 0.045 and $0.070 \mathrm{~mm}$, all $f$ values produced chips mixed with continuous and conical chips. Less connected chips were produced from Conv. $\mu$ Mill process when the $f$ were $4.2 \times 10^{-3}$ $\mathrm{mm} /$ flute. In addition, at $f$ of $4.2 \times 10^{-3} \mathrm{~mm} /$ flute, Conv. $\mu$ Mill produced continuous chips only at $t_{c}$ of $0.020 \mathrm{~mm}$ (Figue 4-a and Figure 5-b). Increasing the $f$ value has consequently increased the uncut chip thickness and reduced the swept angle [31]. At $t_{c}$ of $4.2 \times 10^{-3} \mathrm{~mm} /$ flute, the chips were formed with larger thickness and stiffer. As a result, the chips were produced with consistence shape and less connected compared to the lower $f$ value. Even though the ball milling tool perform interrupted cutting, the chips were connected by compression and heat generated during the cutting process [32]. The connected chips become longer until certain length and flew away for the increasing of weight and collation with work piece or other chips.

Table 3. Chips pattern mapping

\begin{tabular}{|c|c|c|c|c|c|c|c|c|c|c|}
\hline \multirow{2}{*}{$t_{c}(\mathrm{~mm})$} & \multirow{2}{*}{$\begin{array}{l}\text { Machining } \\
\text { technique }\end{array}$} & \multicolumn{3}{|c|}{$f 1$} & \multicolumn{3}{|c|}{$f 2$} & \multicolumn{3}{|c|}{$f 3$} \\
\hline & & $N 1$ & $N 2$ & $N 3$ & $N 1$ & $N 2$ & N3 & $N 1$ & $N 2$ & $N 3$ \\
\hline \multirow{2}{*}{0.020} & $\begin{array}{l}\text { Conv. } \\
\mu \text { Mill }\end{array}$ & (C) & (C) & (C) & $\mathrm{L}$ & $\mathrm{L}$ & $\mathrm{L}$ & $\mathrm{C}$ & $\mathrm{C}$ & $\bigcirc$ \\
\hline & LA $\mu$ Mill & 0 & $\bigcirc$ & 0 & 0 & $\mathrm{~L}$ & $\mathrm{~L}$ & (C) & (C) & (C) \\
\hline \multirow{2}{*}{0.045} & $\begin{array}{l}\text { Conv. } \\
\mu \text { Mill }\end{array}$ & $\mathrm{C}$ & $\mathrm{C}$ & $\mathrm{C}$ & (C) & (C) & (C) & $\mathrm{C}$ & $\mathrm{L}$ & $\mathrm{C}$ \\
\hline & LA $\mu$ Mill & 0 & 0 & 0 & (C) & (C) & (C) & (C) & (C) & (C) \\
\hline \multirow{2}{*}{0.070} & $\begin{array}{l}\text { Conv. } \\
\mu \text { Mill }\end{array}$ & (C) & (C) & (C) & $\mathrm{C}$ & $\mathrm{C}$ & $\mathrm{C}$ & $\mathrm{C}$ & $\mathrm{C}$ & $\mathrm{C}$ \\
\hline & LA $\mu$ Mill & (C) & (C) & (C) & $\mathrm{C}$ & $\mathrm{C}$ & $\mathrm{C}$ & $\mathrm{C}$ & $\mathrm{C}$ & (C) \\
\hline $\begin{array}{l}N 1, N \\
f 1, f 2, \\
\bigcirc \\
\text { C) } \\
\mathrm{C} \\
\mathrm{L}\end{array}$ & $\begin{aligned} 2, N 3 & : 12 . \\
f 3 & : 2.1 \\
& : \operatorname{mix} \\
& : \text { mix } \\
& : \text { con } \\
& : \text { onl }\end{aligned}$ & $\begin{array}{l}x \quad 10 \\
10^{-3} \\
d \text { wit } \\
\text { d wi } \\
\text { al ch } \\
\text { loose }\end{array}$ & $\begin{array}{l}\text { onti } \\
\text { con } \\
\mathrm{c} \mathrm{ch}\end{array}$ & $\begin{array}{l}0^{3}, 2 \\
, 4.2 \\
\text { lous c }\end{array}$ & $\begin{array}{l}\text { X } 10 \\
10^{-3} \\
S\end{array}$ & $\begin{array}{l}\mathrm{ppm} \\
\mathrm{n} / \mathrm{fl}\end{array}$ & & & & \\
\hline
\end{tabular}




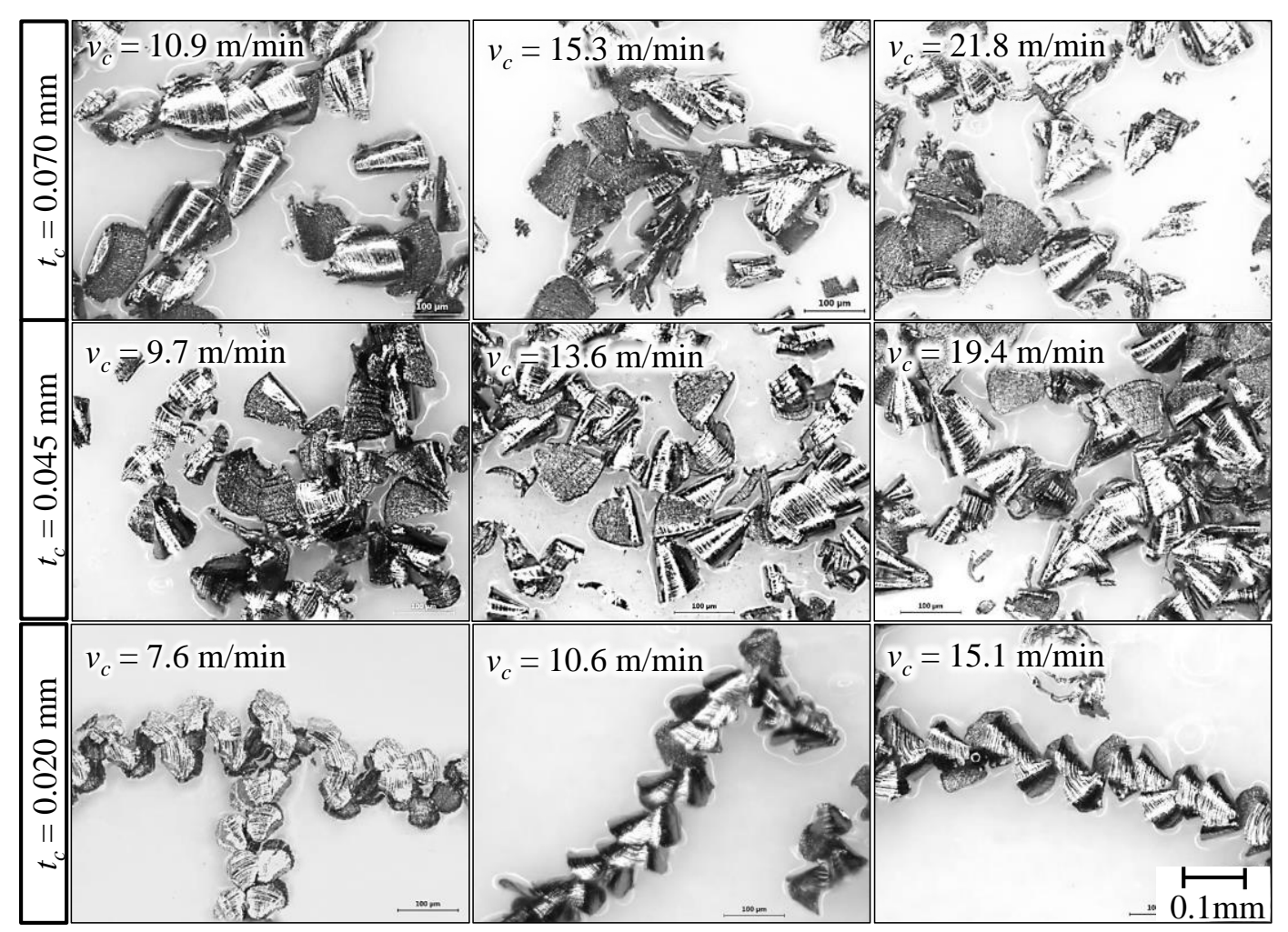

Conv. $\mu$ Mill, $f=2.1 \times 10^{-3} \mathrm{~mm} /$ flute

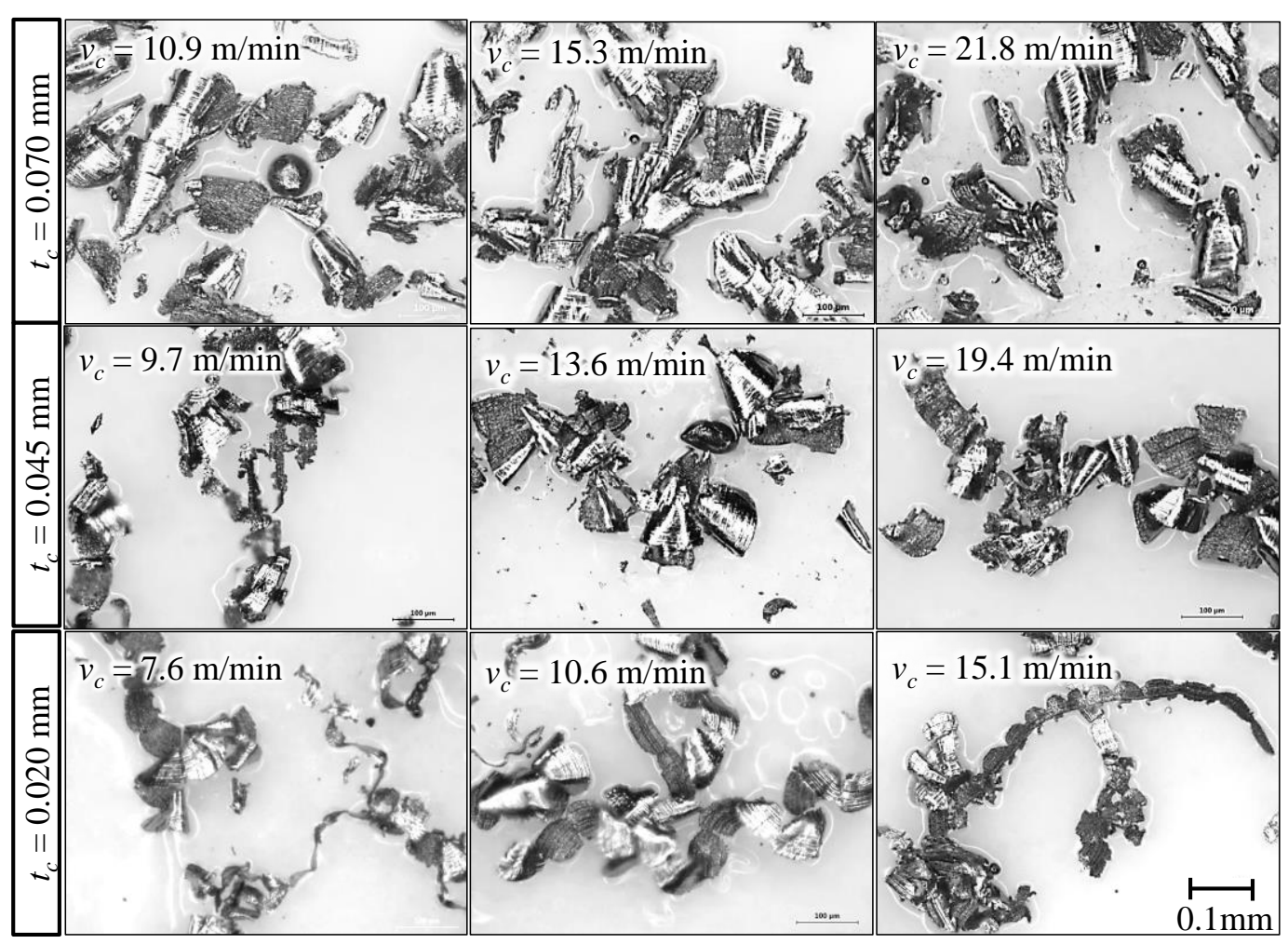

LA $\mu$ Mill, $f=2.1 \times 10^{-3} \mathrm{~mm} /$ flute

Figure 4. Chips pattern from Conv. $\mu$ Mill and LA $\mu$ Mill under different $t_{c}$ and $v_{c}$ when $f$ is $2.1 \times 10^{-3} \mathrm{~mm} /$ flute 


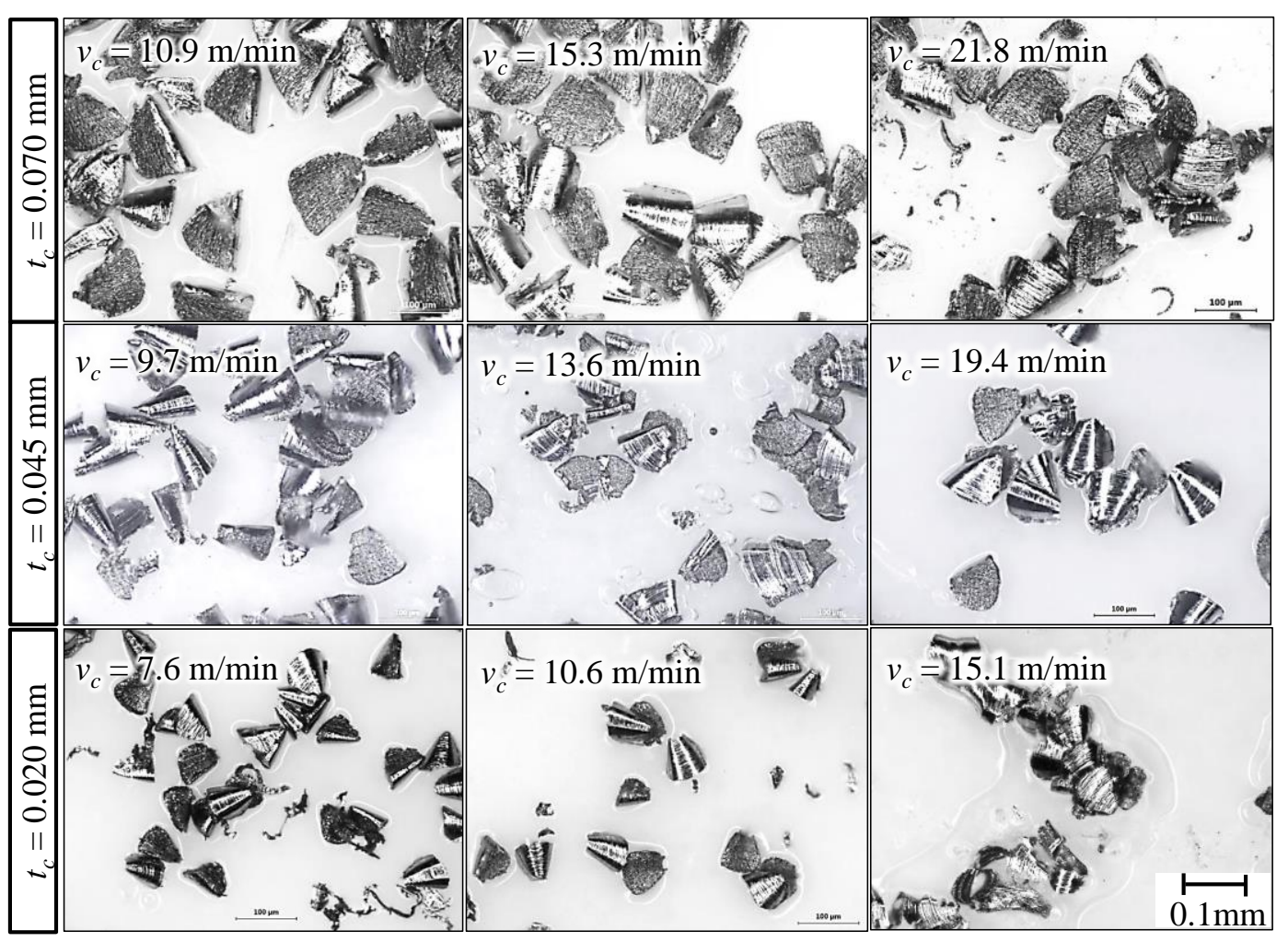

Conv. $\mu$ Mill, $f=4.2 \times 10^{-3} \mathrm{~mm} /$ flute

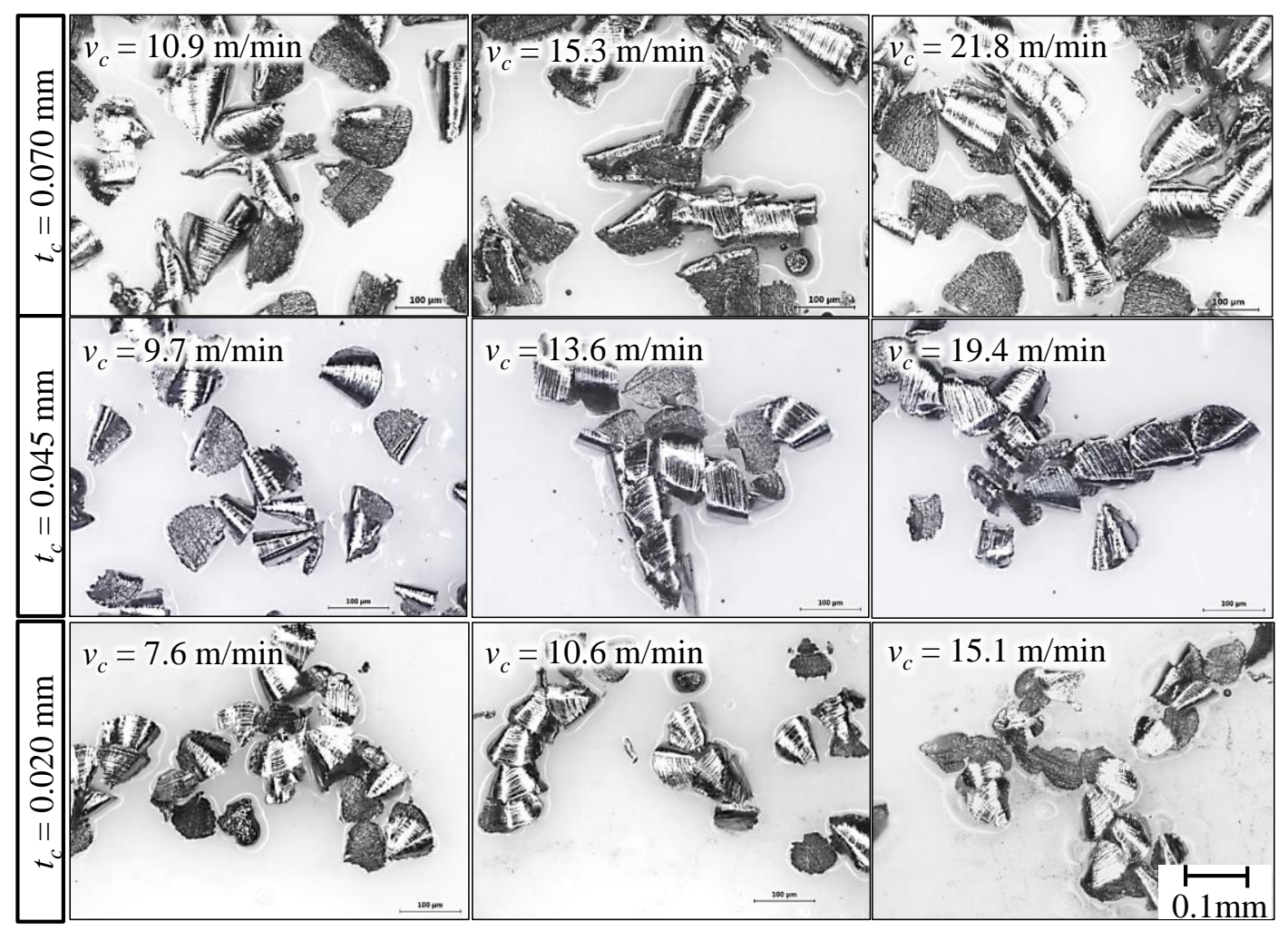

LA $\mu$ Mill, $f=4.2 \times 10^{-3} \mathrm{~mm} /$ flute

Figure 5. Chips collected from Conv. $\mu$ Mill and LA $\mu$ Mill under different $t_{c}$ and $v_{c}$ when $f$ is $4.2 \times 10^{-3} \mathrm{~mm} /$ flute 
On the other hands, when the $f$ was $2.1 \times 10^{-3} \mathrm{~mm} /$ flute, the uncut chip thickness were approximately equal to the tool tip radius. When the uncut chip thickness is equal or less than tool tip radius, the chips will be formed under uneven plastic flow with high ratio of rubbing and ploughing effect due to minus rake angle cutting edge $[26,33]$. Ploughing and rubbing effect has consequently produced thin and connected chips, and inconsistent in shape and size. Generally, increasing the $f$ value from 0.0021 to $0.0042 \mathrm{~mm} /$ flute has changes the chips from continuous to conical.

Increasing the $v_{c}$ in the range between $7.6 \mathrm{~m} / \mathrm{min}$ to $21.8 \mathrm{~m} / \mathrm{min}$ was unable to show different chip formation characteristics as reported by Sun et al. [29]. No sharpteeth and sharp segmented chip were identified. The $v_{c}$ increment were found does not have significant relation with the chip creation characteristics. The chips produced in this study were comparatively too thin and small. The chips were formed under intense plastic deformation and the segmentation distance was independent from cutting speed changes.

It is also observed that the chips were also produced in the similar shape, regardless to the $v_{c}$ applied in LA $\mu$ Mill. It is suggested that the temperature increment initiated by the $v_{c}$ increment were not significant to give influence onto the chip formation behaviour between the both machining techniques (Conv. $\mu$ Mill and LA $\mu$ Mill). The shear and plastic deformation zone were extremely small and unable to generate sufficient heat which can give influence to the workpiece physical properties during the removal process.

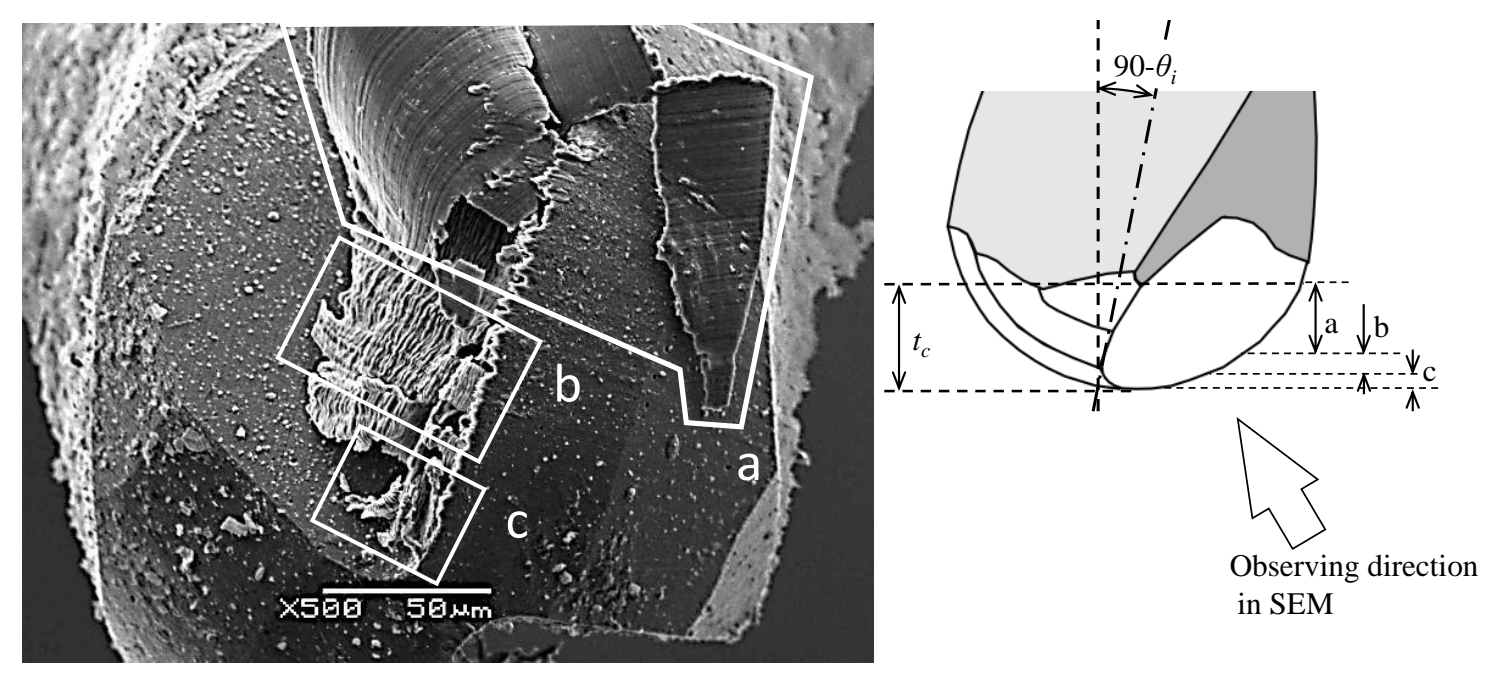

Figure 6. Chip formation in micro ball milling

The variation shapes of chips produced under different $t_{c}$ has a strong relation with the cutting edges location (Figure 6). In this study, the smallest $t_{c}$ of $0.020 \mathrm{~mm}$ was used which is capable to produce two chips patterns (Figure 6-a and Figure 6-b). When the $t_{c}$ is increased to $0.045 \mathrm{~mm}$, the chips shown in Figure 6-b dominated the total chips produced. Groove machining using higher $t_{c}$ of $0.070 \mathrm{~mm}$ produced a higher ratio of conical chips (Figure 6-c).

Since the cutting edges are in radial shape, the chips thickness increases with the $t_{c}$. Unevenly distributed built up edges and comparatively rough tool surface roughness initiate crack and break the chips into smaller pieces. This mechanism has eventually produced chips with pattern as shown in Figure 6-a and Figure 6-b. Increasing the $t_{c}$ to 
$0.070 \mathrm{~mm}$ has further increased the chip thickness and made the chips become larger and stiffer. Consequently, the chips turn to conical as their length and width become too large to fit in the space in front of the tool rake face. At this conditions, the chips were compressed and bent by mechanical force to conical shapes.

LA $\mu$ Mill produced conical and elemental arc shape chips at $t_{c}$ of 0.045 and $0.070 \mathrm{~mm}$. It is obviously can be seen that the chips produced form LA $\mu$ Mill is larger and curlier compared to Conv. $\mu$ Mill (Figure 4-a). Larger chip size is one of the evident that the chips flow out more easily due to lower tensile strength at higher workpiece temperature [28].

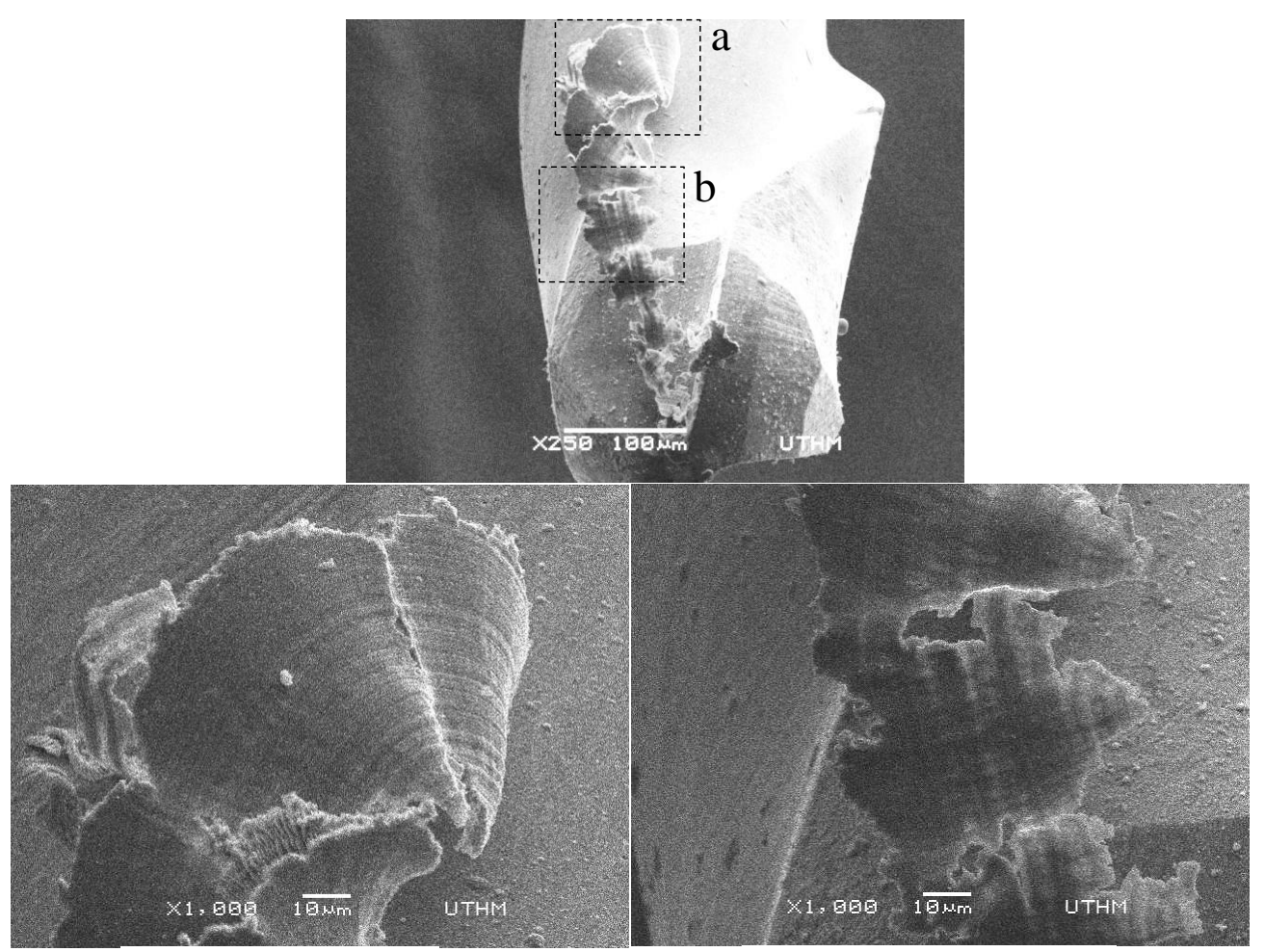

Figure 7. Chips formation in LA $\mu$ Mill

$$
\left(f=3.0 \times 10^{-3} \mathrm{~mm} / \text { flute, } t_{c}=0.020 \mathrm{~mm}, f_{r}=52.5 \mathrm{~mm} / \mathrm{min}\right)
$$

Figure 7 shows the evident of how the chips were formed in LA $\mu$ Mill. Commonly, chips in LA $\mu$ Mill were created in ununiformed shapes. Higher percentage of continuous and conical chips were produced and they were larger in size compared to Conv. $\mu$ Mill. Even though the size of the chips was larger when the $t_{c}$ is increased, less chips were produced in elemental arc shape. The conical chips were connected to form continuous and thin chip. The thin and continuous chips adhered on the cutting edge which performing the cutting process and they were located near to the chisel area. From a single cutting edge, the chips were formed in various thickness and patterns. When the material is heated, the chip size and shape can be more inconsistent due to the increment of plastic behaviour and ductility. Elastic recovery thickness is suggested one of the major reason [31]. Certain thickness of workpiece were left over during the previous cut and removed together with the next tool engagement and created thicker and different chip size and pattern. This phenomenon can be seen obviously at the $f$ of $2.1 \times 10^{-3} \mathrm{~mm} /$ flute which is near to cutting tool tip radius $\left(1 \sim 2 \times 10^{-3} \mathrm{~mm}\right)$. In addition, the heated workpiece has a higher tendency to produce continuous and snarled 
chips [34]. This type of chips frequently interfere the cutting process and gave significant influence on the overall chips pattern.

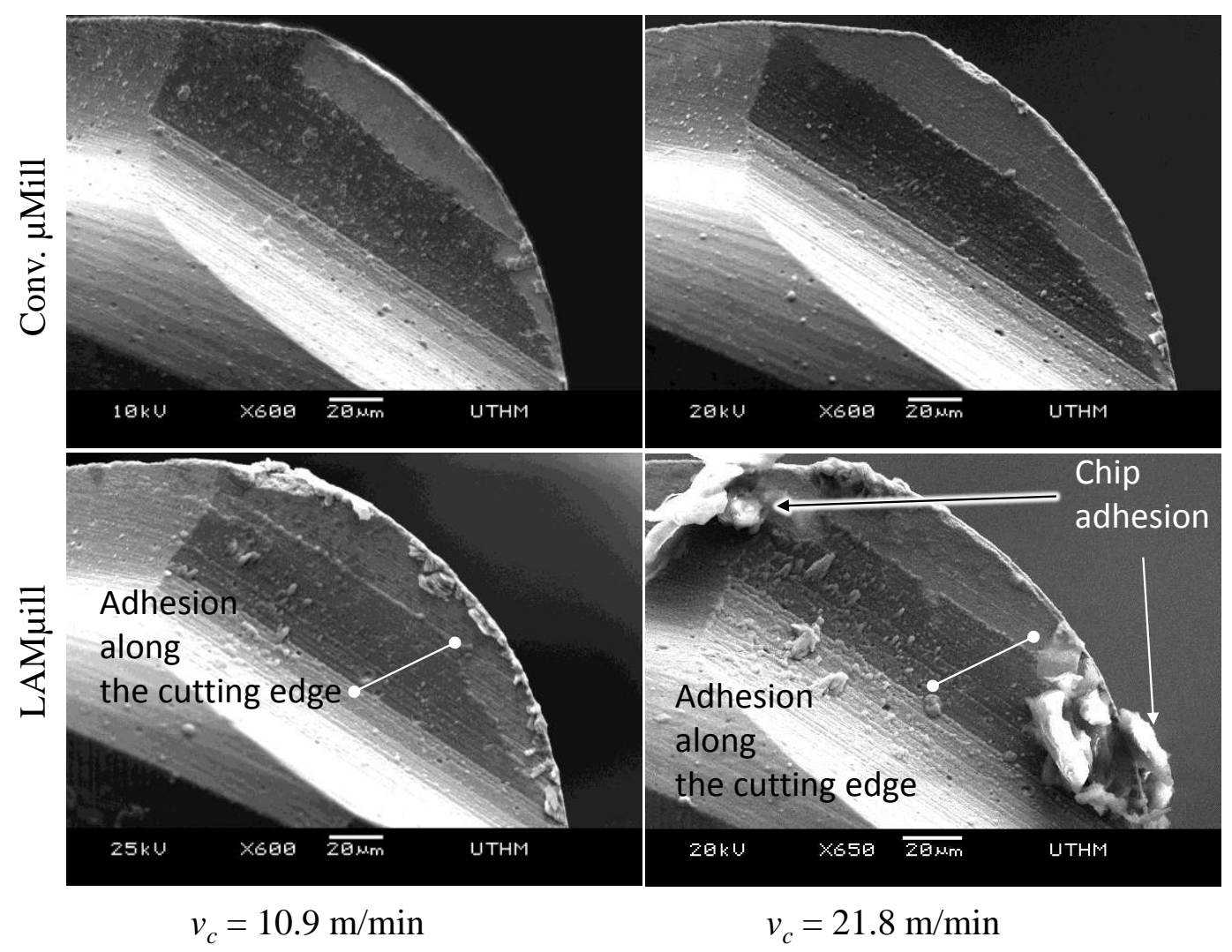

Figure 8. Comparison of adhesion condition between LA $\mu$ Mill and Conv. $\mu$ Mill $\left(f=2.1 \times 10^{-3} \mathrm{~mm} /\right.$ flute, $\left.t_{c}=0.070 \mathrm{~mm}\right)$

At higher workpiece temperature, the adhesions on the cutting tool edges were accumulated more easily and consequently constructed a new cutting edge geometry $[35,36]$. The condition of tool with adhesion can be seen in Figure 6 . The height of adhesion increases with the radial distance from the tool rotation centre. Comparison between LA $\mu$ Mill and Conv. $\mu$ Mill has shown different amount of chip adhesion (Figure 8). In LAMill, the built up edges formed by adhesion can be seen along the cutting tool edge and sometime larger chip adhere near the tool rotation centre and upper location of the cutting edges. As a result, the chips flow out in front of the rake surface in conical shape. As a result, LA $\mu$ Mill produced larger amount of conical chips compared to Conv. $\mu$ Mill.

\section{Burr Formation Characteristics}

Figure 9 shows the condition of the grooves machined by different $f, t_{c}$ and machining methods. The direction of the tool movement is shown in the figure. Left and right side of each grooves were processed by down and up milling respectively.

Both machining methods (Conv. $\mu$ Mill and LA $\mu$ Mill) produced grooves with slot base burr on the up milling cutting surface. The location of slot base burr has shown that the chips were torn and separated from the base material under proper cutting speed and good cutting edges [24]. In this study, the slot base burrs were formed on the up milling surface when the chips adhered on the cutting tool rake surface were compressed during the tool entrance. When the $f$ is increased to $4.2 \times$ 
$10^{-3} \mathrm{~mm} /$ flute, less slot base burr created (Figure 10). Ticker and stronger chips were produced and flowed out from the cutting area more efficiently is suggested to be the main reason. In addition, the milling process was performed under less elastic deformation effect when the uncut chip thickness is larger than minimum chip thickness [8] which need to be in range of $5 \%$ to $38 \%$ of the cutting edge radius [37]. Consequently, fewer chips adhered on the up milling side surfaces.

Figure 10 shows the grooves fabricated using higher $v_{c}$ which ranged from 15.1 to $21.8 \mathrm{~m} / \mathrm{min}$. The groove conditions were not much different compared to Figure 9 which were produced under lower $v_{c}$. Ploughing and rubbing effect dominated the removal process mechanisms in the both $v_{c}$ ranges which consequently worsen the cutting surface appearance $[23,38]$ at lower cutting speed, in LA $\mu$ Mill process and Conv. $\mu$ Mill. Increasing the $v_{c}$ does not give significant effect on the burr condition at $t_{c}$ of 0.020 and $0.045 \mathrm{~mm}$. The amount of slot base burr at the up milling regions were considerably equal.

However, significant difference on slot base burr condition between high and low $v_{c}$ was observed at $t_{c}$ of $0.070 \mathrm{~mm}$. The chips were produced in continuous and conical shapes, and significantly larger than $t_{c}$ of $0.045 \mathrm{~mm}$ and $0.020 \mathrm{~mm}$. At $t_{c}$ of $0.070 \mathrm{~mm}$, the large size of chips compressed on the machining surface created slot base burr and top burr at the up milling machining surface. Larger size of chip compression at higher $v_{c}$ has consequently promoted the slot base bur formation due to higher cutting temperature [35] generated via shearing and friction mechanisms adhere on the tool cutting edges. At the same time, the grooves seemed to be larger in LA $\mu$ Mill. It means that the grooves were produced deeper in LA $\mu$ Mill. The actual $t_{c}$ become larger for the less tool edge positioning error [39], thus produced larger amounts of conical shape chips. This type of chips were being compressed onto the cutting groove up milling sides and remained as slot base burr.

The top burr at the down milling side was produced larger in LA $\mu$ Mill compared to Conv. $\mu$ Mill. This burr was formed by plastic deformation during the cutting process. LA $\mu$ Mill tends to produce continuous chips and rotating together with the cutting tool. This phenomenon shows that LA $\mu$ Mill has a higher tendency for the chips to adhere and blocking the cutting edges which contributes to inconsistence machining performance [40]. The creation of larger top burr at the down milling sides in LA $\mu$ Mill is a significant evidence showing that the workpiece being heated has become softer. Consequently, more obvious plastic deformation occurs during the cutting process. The formation of top burr are obvious at $t_{c}$ of $0.070 \mathrm{~mm}$. It indicates that the $t_{c}$ value is tool large since the ratio of axial depth of cut to ball milling radius need to be considered in micro milling operation with ball end mill tools [24].

Slot base burr were observed in the both machining techniques, Conv. $\mu$ Mill and $\mu$ LAMill. It is a normal phenomenon in micro machining of metal materials [41]. However in the case of this study, slot base burr which formed by chip compression at the up milling side were found larger in LA $\mu$ Mill. It is suggested that, when the workpiece is heated, the workpiece became softer and easier to 

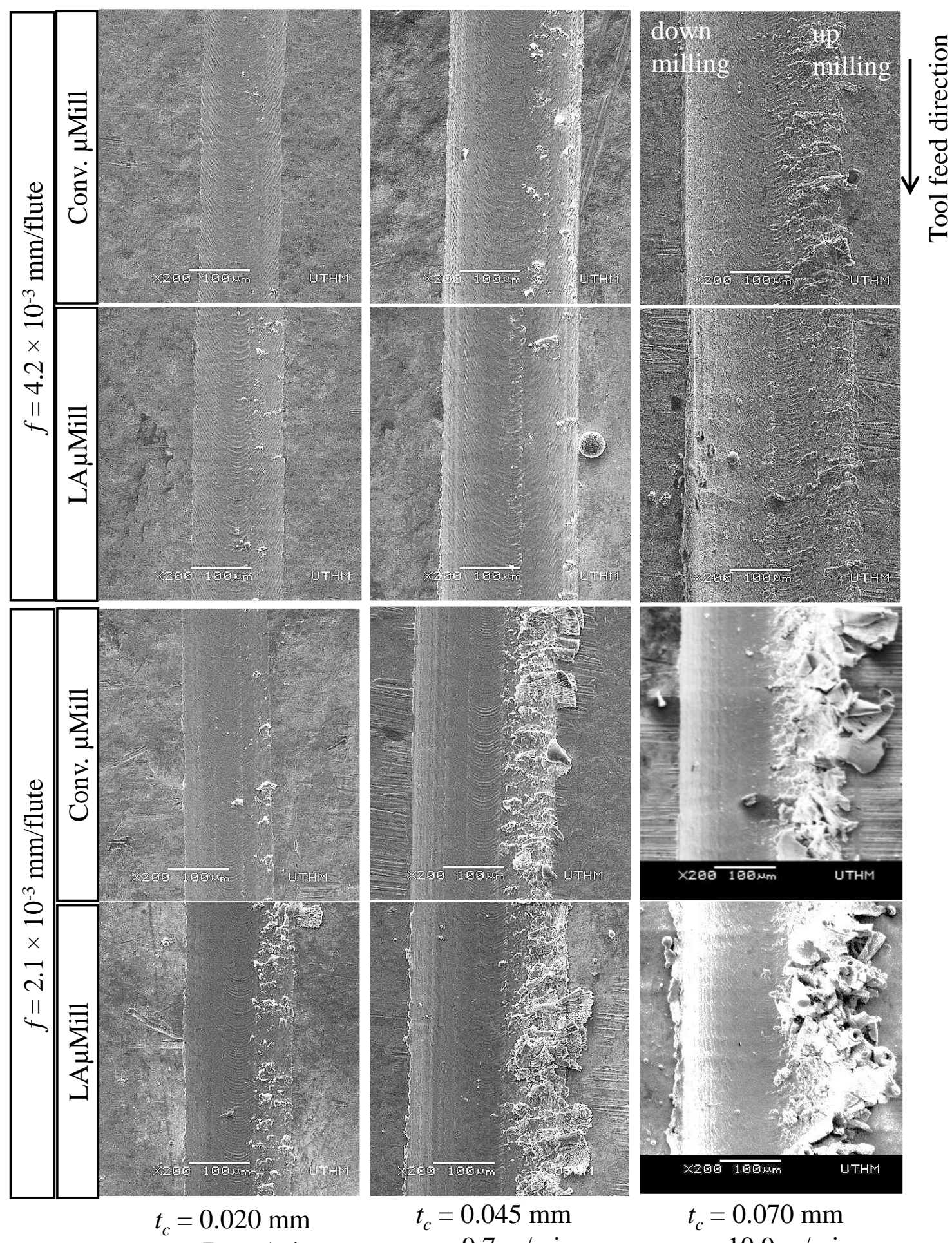

$t_{c}=0.045 \mathrm{~mm}$

$t_{c}=0.070 \mathrm{~mm}$

$v_{c}=7.6 \mathrm{~m} / \mathrm{min}$

$v_{c}=9.7 \mathrm{~m} / \mathrm{min}$

$v_{c}=10.9 \mathrm{~m} / \mathrm{min}$

Figure 9. Machined grooves comparison between different $t_{c}, f$ and machining methods with $v_{c}$ ranged from 7.6 to $10.9 \mathrm{~m} / \mathrm{min}$ 

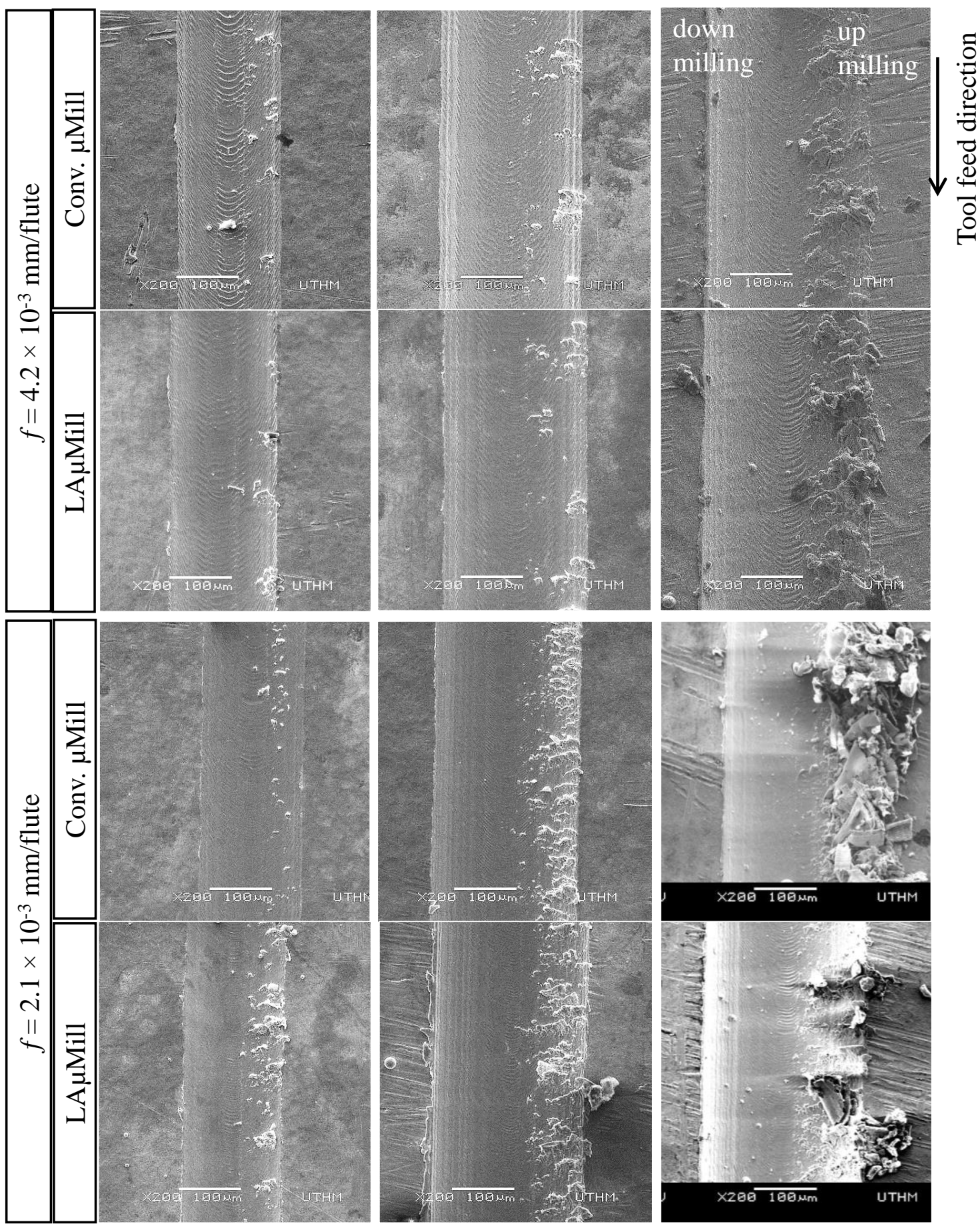

$$
\begin{gathered}
t_{c}=0.020 \mathrm{~mm} \\
v_{c}=15.1 \mathrm{~m} / \mathrm{min}
\end{gathered}
$$

$$
\begin{gathered}
t_{c}=0.045 \mathrm{~mm} \\
v_{c}=19.4 \mathrm{~m} / \mathrm{min}
\end{gathered}
$$

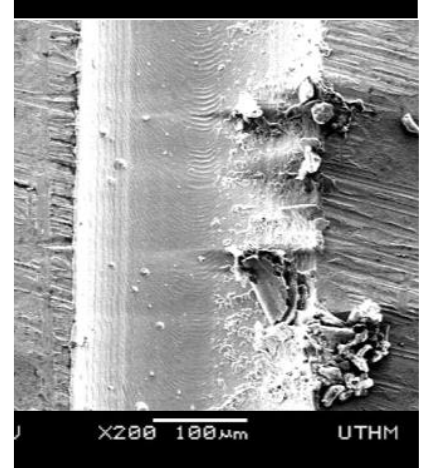

$$
\begin{gathered}
t_{c}=0.070 \mathrm{~mm} \\
v_{c}=21.8 \mathrm{~m} / \mathrm{min}
\end{gathered}
$$

Figure 10. Machined grooves comparison between different $t_{c}, f$ and machining methods with $v_{c}$ ranged from 15.1 to $21.8 \mathrm{~m} / \mathrm{min}$

Referring to the thermal dependant properties of Ti6Al4V, heating the material from $20{ }^{\circ} \mathrm{C}$ to $200^{\circ} \mathrm{C}$ will give softening effect to the workpiece. Young's modulus is expected to reduce from 114 to $105 \times 10^{5}\left(\mathrm{~N} \cdot \mathrm{mm}^{-2}\right)$ [42], while the density will reduce from 4.42 to $4.39 \times 10^{3}\left(\mathrm{Kg} \cdot \mathrm{mm}^{3}\right)$ [7]. Calcualtion using modified Johnson Cook material model [23] estimated that the flow stress will 
resuce for approximately $14 \%$ when the material heated from 20 to $200{ }^{\circ} \mathrm{C}$. The properties changes occur during LA $\mu$ Mill has caused different chip formation and machining characteristics between the two different machining techniques.

The difference in burr creation has shown that the micro ball end mill is insufficient for deep grove machining. The chips produced at every tool engagement need to be efficiently removed to avoid chip compression at the machining area.

\section{Surface Roughness}

Figure 11 shows the surface roughness $\left(R_{a}\right)$ of the groove bottom surfaces. Alphabet $\mathrm{C}$ and $\mathrm{L}$ represent the machining techniques used in the experiment $(\mathrm{C}$ : Conv. $\mu$ Mill, L: LA $\mu$ Mill). The measurements were taken at three point; entrance, centre and exit part of the machined grooves. The $R_{a}$ values were compared between different machining techniques under three different depth of cut $\left(t_{c}\right)$, three different feed $(f)$ and various cutting speeds $\left(v_{c}\right)$.

The $R_{a}$ fluctuated and changed differently at different $t_{c}$. At $t_{c}$ of $0.020 \mathrm{~mm}, R_{a}$ increased with $f$. However, the increment was not significant. At $f$ of $4.2 \times 10^{-3}$ $\mathrm{mm} /$ flute, the $R_{a}$ value fluctuated significantly larger than $f$ of 2.1 and $3.0 \times 10^{-3}$ $\mathrm{mm} /$ flute. Larger size of connected chips are suggested to be the major reason. The connected chips generated at $t_{c}$ of $0.020 \mathrm{~mm}$ became thicker when the $f$ is increased. Low chip evacuation efficiency of connected chips is suggested to give influence to $R_{a}$ by tangling around the cutting area during the machining process.

The relation between $f$ and $R_{a}$ was unable to be seen at $t_{c}$ of $0.045 \mathrm{~mm}$. There were also less significant roughness different between $f$ of 2.1 and $3.0 \times 10^{-3} \mathrm{~mm} /$ flute. It is suggested that the $f$ values $\left(2.1\right.$ and $\left.3.0 \times 10^{-3} \mathrm{~mm} / \mathrm{flute}\right)$ were too close to the cutting edge radius $\left(1 \sim 2 \times 10^{-3} \mathrm{~mm}\right)$, thus the cutting process was dominated by rubbing and ploughing effect. In the case of $t_{c}$ of $0.070 \mathrm{~mm}$, when the $f$ was increased to $4.2 \times$ $10^{-3} \mathrm{~mm} /$ flute, the chips became thicker and stiffer which caused the connected chips to be more easily to disconnected and flow out from the cutting area. This has caused the $R_{a}$ becomes more consistent at $f$ of $4.2 \times 10^{-3} \mathrm{~mm} /$ flute compared to 2.1 and $3.0 \times 10^{-3}$ $\mathrm{mm} /$ flute when the $t_{c}$ was $0.070 \mathrm{~mm}$.

The $R_{a}$ fluctuation range increases with the $t_{c}$. Larger volume of chips produce per each tool engagement will consequently increase the forces act on the cutting tool. It is suggested that larger and thicker chips involved in rubbing mechanism has caused ploughing effect to be more influencing the machining surface condition. Rapid flank wear propagation at larger $t_{c}$ also suggested to give significant effect to the $R_{a}$ value. As a result, higher $t_{c}$ produced larger $R_{a}$ value fluctuation.

Overall, $v_{c}$ gave less significant influence to $R_{a}$ value (Figure 11). However, the $R_{a}$ increases with $f_{r}$ when the $f$ and $t_{c}$ were $2.1 \times 10^{-3} \mathrm{~mm} /$ flute and $0.070 \mathrm{~mm}$ respectively. For the reason that the tool cutting edges radius is approximately $2.0 \times 10^{-3}$ $\mathrm{mm}$, the process is dominated by rubbing mechanism [31]. Increasing the $v_{c}$ will consequently enhance the effect of ploughing and plastics deformation. These has caused the $R_{a}$ value and fluctuation range to increase.

At higher $f$ of 3.0 and $4.2 \times 10^{-3} \mathrm{~mm} /$ flute, the increment of $v_{c}$ from 7.6 to 21.8 $\mathrm{m} / \mathrm{min}$ did not gave significant $R_{a}$ changing trend. The machining process was performed under adiabatic shear mechanism which involved poor heat dissipation and intense shear concentration [43-45]. The shear and deformation area is too small and unable to generate significant temperature difference which could bring influence to the $R_{a}$ value via softening effect. Consequently, the value of $R_{a}$ were kept approximately at the same level even though the $v_{c}$ were increased to double. 

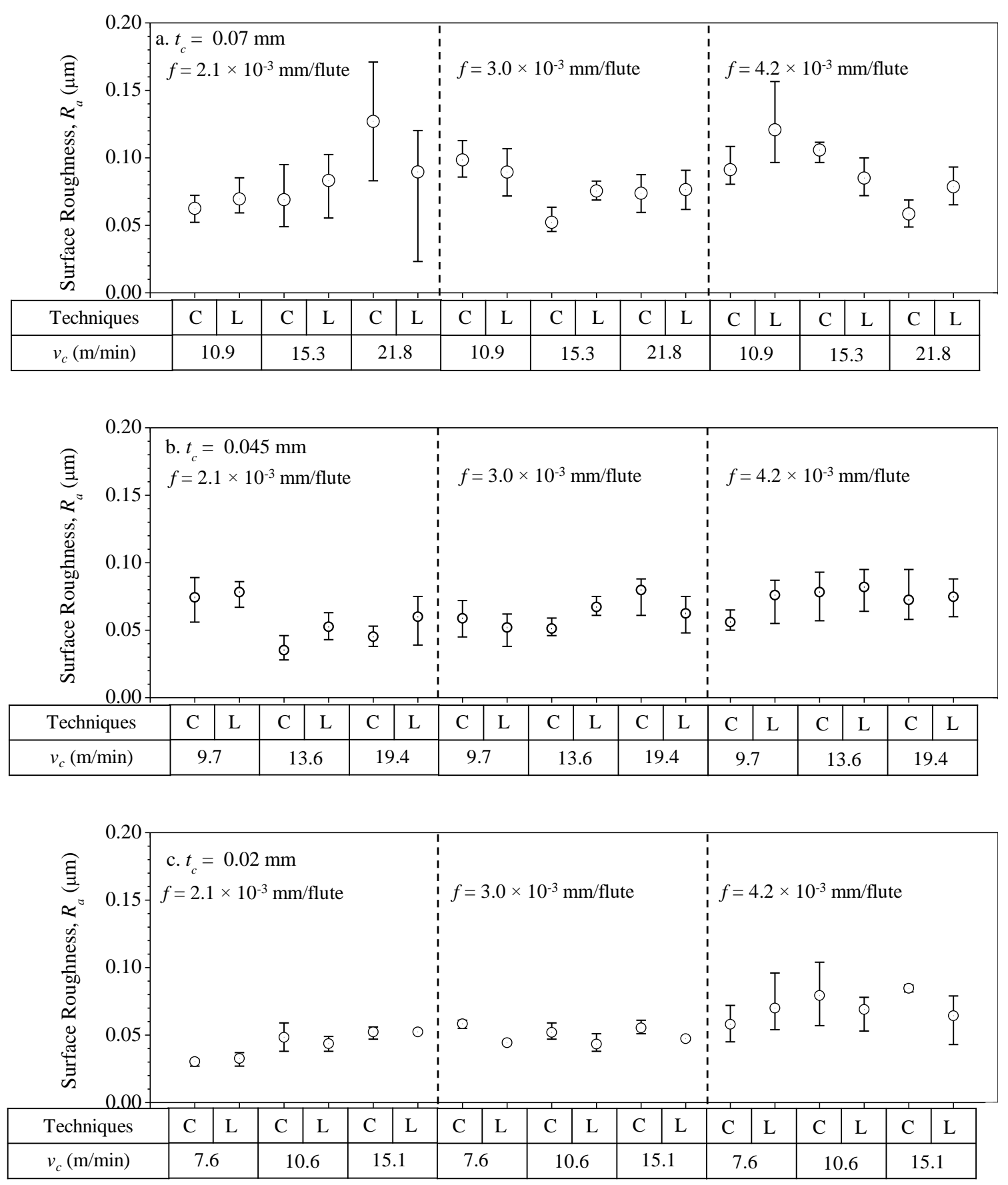

Figure 11. Surface roughness $\left(R_{a}\right)$ for cutting distance $\left(X_{c}\right)$ between 25 to $50 \mathrm{~mm}$ when $t_{c}$ were $0.020 \mathrm{~mm}$

One quarter of the parameters used in the study has shown larger $R_{a}$ value when laser heating is applied. LA $\mu$ Mill has generally shown larger $R_{a}$ at $t_{c}$ of $0.070 \mathrm{~mm}$. Heating process in LA $\mu$ Mill has caused the workpiece became more ductile $[5,6]$ and produced curly chips with inconsistence size and shape. This chips has higher tendency to stick on the cutting surface by rubbing and ploughing mechanisms. A lot of chips 
were found sticking on the cutting surface near the groove centre line. This has made the $R_{a}$ to be larger than Conv. $\mu$ Mill.

The effect of laser heating to the reduction of $R_{a}$ only can be observed at $t_{c}$ of $0.020 \mathrm{~mm}$ when the $f$ were 3.0 and $4.2 \times 10^{-3} \mathrm{~mm} /$ flute (Figure 11). The $R_{a}$ value reduced for approximately $12 \%$ to $20 \%$ when laser heating were applied. It is suggested that lower material strength and better chips flow [46] compared to the $t_{c}$ of $0.070 \mathrm{~mm}$ has contributed largely to $R_{a}$ reduction. Less $R_{a}$ reduction was recorded at higher $v_{c}$ value due to lower workpiece temperature achieved in LA $\mu$ Mill.

\section{CONCLUSION}

Through the experimental results, the feasibility of micro ball end mill in LA $\mu$ Mill was successfully evaluated. LA $\mu$ Mill under heating temperature of $130{ }^{\circ} \mathrm{C}$ to $180{ }^{\circ} \mathrm{C}$ has shown different machining characteristics. From the results of chips formation characteristics, burr and surface conditions, the next conclusions are derived.

Feed of $4.2 \times 10^{-3} \mathrm{~mm} /$ flute produced the most consistent chips pattern with less connected chip. In contrast, at feed of $2.1 \times 10^{-3} \mathrm{~mm} /$ flute, most of the chips were produced in continuous shape.

Cutting speed in range between $7.6 \mathrm{~m} / \mathrm{min}$ and $21.8 \mathrm{~m} / \mathrm{min}$ does not give significant influence to the chip pattern and burr formation characteristics in the both machining techniques (LA $\mu$ Mill and Conv. $\mu$ Mill).

Chips pattern show a strong relation with the machining surface roughness consistency. Under the depth of cut of $0.020 \mathrm{~mm}$, the feed value of $3.0 \times 10^{-3}$ $\mathrm{mm} /$ flute has shown comparably consistent surface roughness under different cutting speed. Loose arc chips produced at this machining parameter allows the machining to be performed with less chip blocking, ploughing and rubbing mechanism which consequently produced consistent surface roughness.

Machining under the depth of cut 0.045 and $0.070 \mathrm{~mm}$ has resulted to inconsistence surface roughness at all feed value and cutting speed applied due to the existence of connected and conical chips.

Laser heating in LA $\mu$ Mill promoted the slot base burr creation by increasing the tendency of chip adhesion on cutting tool and the frequency of connected chip creation.

Machining at $t_{c}$ of 0.045 and $0.070 \mathrm{~mm}$ are not recommended for the both machining techniques (Conv. $\mu$ Mill and LA $\mu$ Mill) due to excessively large chip size. Severe chips compression and poor chip flow led to serious burr formation and poor surface roughness.

\section{ACKNOWLEDGEMENTS}

This study is supported by the funding from the Ministry of Science Technology and Innovation (MOSTI) of Malaysia under Science Fund Research Grant, vot number S020. It is also supported by the SLAB/SLAI scholarship from the Ministry of High Education of Malaysia and Universtiti Tun Hussein Onn Malaysia. 


\section{REFERENCES}

[1] Melkote S, Kumar M, Hashimoto F., Lahoti G. Laser assisted micro-milling of hard-to-machine materials. CIRP Annals - Manufacturing Technology. 2009;58:45-48.

[2] Ding H, Shen N, Shin YC. Thermal and mechanical modelling analysis of laserassisted micro-milling of difficult-to-machine alloys. Journal of Materials Processing Technology. 2012;212:601-613.

[3] Dumitrescu P, Koshy P, Stenekes J, Elbestawi MA. High-power diod laser assisted hard turning of AISI D2 tool steel. International Journal of Machine Tools \& Manufacture 2006;46:2009-2016.

[4] Breacher C, Rosen CJ, Emints M. Laser-assisted Milling of Advanced Materials. Physics Procedia. 2010;5:259-272.

[5] Ayed Y, Germain G, Ben SW, Hamdi H. Experimental and numerical study of laser-assisted machining of Ti6A14V titanium alloy. Finite Elements in Analysis and Design. 2014;92:72-79.

[6] Özel T, Pfefferkorn F. Pulsed laser assisted micromilling for die/mold manufacturing. ASME 2007 International Manufacturing Science and Engineering Conference, American Society of Mechanical Engineers; 2007:337342.

[7] Yang J, Sun S, Brandt M, Yan W. Experimental investigation and 3D finite element prediction of the heat affected zone during laser assisted machining of Ti6Al4V alloy. Journal of Materials Processing Technology. 2010;210:22152222.

[8] Ducobu F, Filippi E, Rivière-Lorphèvre E. Chip formation and minimum chip thickness in micro-milling. Proceeding of the 12th CIRP Conference on Modelling of Machining Operations; 2009:339-346.

[9] Ducobu F, Rivière-Lorphèvre E. Ilippi E. On the importance of the choice of the parameters of the Johnson-Cook constitutive model and their influence on the results of a Ti6Al4V orthogonal cutting model. International Journal of Mechanical Sciences. 2017;122:143-155.

[10] Zeah MF, Weidenmann R, Daub R. A thermal simulation model for laserassisted milling. Physics Procedia. 2010;5:353-362.

[11] Zamani H, Hermani JP, Sonderegger B, Sommitsch C. 3D simulation and process optimization of laser assisted milling of Ti6Al4V. Procedia CIRP. 2013;8:75-80.

[12] Yang B, Lei S. Laser-assisted milling of silicon nitride ceramic: a machinability study. International Journal of Mechatronics and Manufacturing Systems. 2008;1:116-130.

[13] Bermingham MJ, Sim WM, Kent D, Gardiner S, Dargusch MS. Tool life and wear mechanisms in laser assisted milling Ti-6Al-4V. Wear. 2015;322:151-163. 
[14] Lee CM, Kim DH, Baek JT, Kim EJ. Laser assisted milling device: A review. International Journal of Precision Engineering and Manufacturing - Green Technology. 2016;3:199-208.

[15] Cha NH, Lee CM. A study on machining characteristics of silicon nitride with spline members in laser-assisted turn-mill. International Journal of Precision Engineering and Manufacturing. 2015;16:2691-2697.

[16] Kim DH, Lee CM. A study of cutting force and preheating-temperature prediction for laser-assisted milling of Inconel 718 and AISI 1045 steel. International Journal of Heat and Mass Transfer. 2014;71:264-274.

[17] Kim DH, Lee CM. A study on the laser-assisted ball-end milling of difficult-tocut materials using a new back-and-forth preheating method. International Journal of Advanced Manufacturing Technology. 2016;85:1825-1834.

[18] Sim MS, Lee CM. Determination of optimal laser power according to the tool path inclination angle of a titanium alloy workpiece in laser-assisted machining. International Journal of Advanced Manufacturing Technology. 2016;83:17171724.

[19] Matsumura T, Ono T. Cutting process of glass with inclined ball end mill. Journal of Materials Processing Technology. 2008;200:356-363.

[20] Luo S, Bayesteh A, Ko J, Dong Z, Jun MB. Numerical simulation of chip ploughing volume in micro ball-end mill machining. International Journal of Precision Engineering and Manufacturing. 2017;18:915-922.

[21] Arif M, Rahman M, San WY. An experimental investigation into micro ball endmilling of silicon. Journal of Manufacturing Processes. 2012;14:52-61.

[22] Bordin A, Sartori S, Bruschi S, Ghiotti A. Experimental investigation on the feasibility of dry and cryogenic machining as sustainable strategies when turning Ti6Al4V produced by Additive Manufacturing. Journal of Cleaner Production. 2017;142:4142-4151.

[23] Thepsonthi T, Ozel T. 3-D finite element process simulation of micro-end milling Ti-6Al-4V titanium alloy: Experimental validations on chip flow and tool wear. Journal of Materials Processing Technology. 2015;221:128-145.

[24] Chen MJ, Ni HB, Wang ZJ, Jiang Y. Research on the modelling of burr formation process in micro-ball end milling operation on Ti6Al4V. International Journal of Advanced Manufacturing Technology. 2012;62:901-912.

[25] Filiz S, Xie L, Weiss LE, Ozdoganlar OB. Micromilling of microbarbs for medical implants. International Journal of Machine Tools and Manufacture. 2008);48:459-472.

[26] Bajpai V, Kushwaha AK, Singh RK. Burr formation and surface quality in high speed micromilling of titanium alloy (Ti6Al4V). Proceeding of the ASME 2013 International Manufacturing Science and Engineering Conference MSEC2013, Wiscounsin: 2013;1-8.

[27] Molinari A, Musquar C, Sutter G. Adiabatic shear banding in high speed machining of Ti-6Al-4V: experiments and modelling. International Journal of Plasticity. 2002;18:443-459. 
[28] Veiga C, Davim JP, Loureiro AJ. Review on machinability of titanium alloys: The process perspective. Reviews on Advanced Materials Science. 2013;34:148164.

[29] Sun S, Harris J, Brandt M. Parametric investigation of laser-assisted machining of commercially pure titanium. Advanced Engineering Materials. 2008;10:565572.

[30] Fontaine M, Moufki A, Devillez A, Dudzinski D. Modelling of Cutting Forces in Ball-End Milling with Tool-Surface Inclination Part I: Prediction force Model and Experimental Validation. Journal of Material Processing Technology. 2007;189:73-84.

[31] Aramcharoen A, Mativenga PT. Size effect and tool geometry in micromilling of tool steel. Precision Engineering. 2009;33:402-407.

[32] Bayoumi AE, Xie JQ. Some metallurgical aspects of chip formation in cutting Ti-6wt.\% Al-4wt.\% V alloy. Materials Science and Engineering: A. 1995;190:173-180.

[33] Kim CJ, Bono M, Ni J. Experiment analysis of chip formation in micro-milling. Technical Papers - Society of Manufacturing Engineers 2002; All Series.

[34] Weinert K, Kahnis P, Petzoldt V, Peters C. Micro-milling of steel and NiTi SMA. 55th. CIRP General Assembly, STC-C section meeting presentation file, Antalya, Turkey, 2005.

[35] Vazquez E, Gomar J, Ciurana J, Rodríguez C. Analyzing effects of cooling and lubrication conditions in micromilling of Ti6Al4V. Journal of Cleaner Production. 2015;87:906-913.

[36] Wang Z, Kovvuri V, Araujo A, Bacci M, Hung WNP, Bukkapatnam STS. Builtup-edge effects on surface deterioration in micromilling processes. Journal of Manufacturing Processes. 2016;24:321-327.

[37] Filiz S, Conley CM, Wasserman MB, Ozdoganlar OB. An experimental investigation of micro-machinability of copper 101 using tungsten carbide micro-endmills. International Journal of Machine Tools \& Manufacture. 2007);47:1088-1100.

[38] Malekian M, Park SS, Jun MBG. Tool wear monitoring of micro-milling operations. Journal of Materials Processing Technology. 2009;209:4903-4914.

[39] Koc M, Ozel T. Micro-Manufacturing: Design and Manufacturing of MicroProducts. Hoboken: Wiley; 2011.

[40] Jawaid A, Sharif S, Koksal S. Evaluation of wear mechanisms of coated carbide tools when face milling titanium alloy. Journal of Materials Processing Technology. 2000;99:266-274.

[41] Takács M, Verö B, Mészáros I. Micromilling of metallic materials. Journal of Materials Processing Technology. 2003;138:152-155.

[42] Welsch G, Boyer R. Collings EW. (Ed.). Materials Properties Handbook: Titanium Alloys. Ohio, USA: ASM International; 1993.

[43] Komanduri R, Turkovich BF Von. New observation on the mechanism of chip formation when machining titanium alloys. Wear. 1981;69: 179-188. 
[44] Sima M, Özel T. Modified material constitutive models for serrated chip formation simulations and experimental validation in machining of titanium alloy Ti-6Al-4V. International Journal of Machine Tools and Manufacture. 2010;50:943-960.

[45] Pramanik A. Problems and solutions in machining of titanium alloys. International Journal of Advanced Manufacturing Technology. 2014;70:919928.

[46] Chang W, Sun J, Luo X, Ritchie JM, Mack C. Investigation of microstructured milling tool for deferring tool wear. Wear. 2011;271:2433-2437. 